Nama

NRP

$\mathrm{KP}$

Mata Kuliah
: Amanda Dara Lita

: 130119075

:A

: Simulasi Mikro Ekonomi Dalam Bisnis

\title{
Penjabaran Teori Kontingensi dan Pengaruh Suatu Moderating Variable Terhadap Suatu Model Serta Peran Mediating Effect Dalam Suatu Perusahaan
}

Teori kontingensi adalah teori perilaku dimana teori tersebut berpendapat bahwa tidak ada satu cara terbaik untuk memimpin dan gaya kepemimpinan yang efektif dalam beberapa situasi mungkin tidak akan berhasil dalam situasi lain. Teori kontingensi manajerial bisa membantu mengatasi beberapa kesenjangan dalam literatur dengan menjelaskan faktor-faktor yang mempengaruhi keputusan manajer dalam mengadopsi suatu teknologi. Dimana teori ini memiliki pengaruh positif dan signifikan secara statistik terhadap adopsi teknologi, akan tetapi kurangnya kepemimpinan, sistem warisan dan kurangnya pemahaman tentang teknologi memiliki efek negatif dan signifikan secara statistik. Teori ini juga menunjukkan bahwa variasi dalam adopsi teknologi dapat dijelaskan oleh variasi dalam insentif, kendala dan konteks yang dihadapi oleh pengelola. Ciri utama dari teori kontingensi manajerial adalah fokus pada motivasi dan kendala yang dihadapi (Araral, 2020) Pengaruh teori kontingensi struktural dengan literatur tentang hierarki kekuasaan pada kinerja usaha baru bergantung pada latar belakang fungsional dan pengalaman tim bersama serta pengalaman pendiri pemegang kekuasaan sebelumnya. Teori kontingensi struktural dapat diperluas dengan mempertimbangkan berbagai kemungkinan komposisi tim dan orang yang bertanggung jawab, yang secara interaktif mempengaruhi efek struktur kekuasaan. Teori kontingensi struktural berfokus pada persyaratan situasional untuk struktur unit kerja, literatur tentang hierarki, dan kekuasaan (Xiao-Yun, 2020) Pengiriman Ekonomi Terkendali Kontingensi Pencegahan (PCCED) dicalonkan di bawah lingkungan yang dideregulasi ditentukan dengan menggunakan konsep solusi (Mojgan Mollahassani, 2020)

Kontinjensi utama dari tugas organisasi suatu perusahaan yaitu memang membentuk hubungan kinerja dimana pengaruh tekanan resesi sebagai kontingensi eksternal pada hubungan kinerja akan mengikuti alasan pandangan kontingen pada hubungan kinerja sumber daya. Hasilnya berdasarkan pandangan kontingen dari hubungan sumber daya ke kinerja, bahwa nilai 
strategis terdapat pada peran pendukungnya guna mencapai kesesuaian antara perusahaan dan lingkungannya. Oleh karena itu, kepemilikan mungkin memang hanya bernilai bagi perusahaan yang beroperasi di bawah kontinjensi tertentu yang menuntut fleksibilitas dan adaptasi. Dalam kontijensi eksternal hubungan antara sumber daya dan kinerja perusahaan sangat bergantung pada kontinjensi lingkungan tugas perusahaan. Dengan demikian kombinasi sumber daya dan lingkungan tugas organisasi akan mempengaruhi kinerja perusahaan. Sumber daya memiliki nilai kontingen. Dapat disimpulkan bahwa implikasi kinerja dari sumber daya perusahaan memerlukan pertimbangan kontinjensi lingkungan. Bahwa lingkungan tugas perusahaan terdiri dari kontinjensi penting yang memoderasi hubungan kinerja (Christopher Jung, 2020)

Teori kontingensi dengan pandangan berbasis sumber daya sebagai teori pendukung untuk mendukung hipotesis yang membahas tentang dampak informasi dan signifikansinya. Yang menjadi dasar dari teori kontingensi adalah bahwa perusahaan akan mencapai kinerja yang terbaik ketika memiliki struktur yang relevan untuk menangani kontinjensi yang dikenakan oleh ukuran, teknologi, dan lingkungan. Teori kontingensi sendiri memiliki maksud untuk memahami bagaimana suatu perusahaan bisa menyelaraskan apa yang diharapkan dalam kinerja dengan lingkungan bisnis internal dan eksternal. Perusahaan tidak hanya perlu memperoleh dan mengembangkan sumber daya mereka tetapi juga perlu meningkatkan kemampuan untuk menghadapi turbulensi lingkungan. Teori kontingensi menunjukkan perilaku perusahaan, yang diperlukan untuk kelangsungan hidup. Turbulensi merupakan proses yang mengubah dampak variabel independen pada FP dalam konteks teori kontingensi (Pratono, 2016)

Teori kontigensi mengambil pandangan yang lebih luas mencakup faktor kontingen tentang kapabilitas dan variabel lain dalam situasi itu sendiri, menghubungkan keefektifan pemimpin dengan aspek situasi dalam suatu organisasi. Organisasi yang terdiri dari banyak strategi, teknologi, dan lingkungan, teori kontigensi menunjukkan efektivitas organisasi dapat dicapai dengan variabel-variabel tersebut. Teori kontigensi ini memberikan petunjuk tentang faktor apa saja yang dapat mendorong ke satu sisi atau sisi lain, yang akhirnya bergantung pada organisasi untuk memutuskan mana yang paling sesuai untuk situasi yang ada. Contoh dari variabel kontinjensi yaitu, manajemen strategi, pemasaran, dan keuangan. Saat turbulensi kontingensi cenderung terdesentralisasi. Contoh turbulensi yaitu, laju perubahan, inovasi, dan pesaing. Turbulensi dalam pasar dan teknologi akan memberi tekanan kuat dan menentukan 
kinerja dalam jangka waktu panjang . Jadi semakin berani mengambil resiko semakin bagus performanya.

Peran efek mediasi adalah untuk kemudahan penyajian dan penjelasan, serta peringkat tahunan yang lebih tinggi. Efek mediasi memberi pengaruh tanggung jawab sosial perusahaan pada investor institusional.Variabel mediasi yang diusulkan adalah kinerja keuangan. Meskipun ada literatur yang luas tentang pengukuran kinerja yang tepat, dan literatur ini telah menyebabkan sedikit konsensus tentang pendekatan terbaik untuk diambil, kinerja keuangan, dalam penelitian ini, dinyatakan dengan pengembalian aset karena mencerminkan hasil operasi daripada keputusan. pengujian efek mediasi dapat dilakukan dalam tiga langkah: pertama, melakukan regresi mediator terhadap variabel independen. Kedua, regresi variabel dependen terhadap variabel independen. Ketiga, regresi variabel dependen baik variabel independen maupun mediator. Mereka menunjukkan bahwa variabel independen dalam dua model pertama diharapkan menunjukkan signifikansi statistik, sedangkan model ketiga diharapkan menunjukkan signifikansi statistik dari variabel mediator dan tidak signifikannya variabel independen (Hayam Wahbaa, 2015) untuk mengukur pengaruh yang tidak dimediasi oleh variabel lain dalam model atau lebih tepatnya, sensitivitas variabel dependen terhadap perubahan variabel independen sedangkan semua faktor lain dalam analisis adalah konstan. Kompetensi wirausaha memiliki peran yang signifikan dalam menentukan kinerja UMKM, dimana adanya pengaruh mediasi kompetensi wirausaha terhadap kinerja UMKM (Amare Abawa Esubalew, 2020)

Menurut mode fungsinya, ketergantungan tidak langsung dapat lebih jauh dibedakan sebagai efek mediasi. Metode analisis efek moderasi / mediasi yang biasa digunakan dalam penelitian psikologi pertama kali digunakan untuk mengurangi subjektivitas. Model fundamental untuk memoderasi analisis efek dan analisis efek mediasi adalah analisis regresi multivariat. Oleh karena itu, hasil analisis efek moderasi / efek mediasi diinterpretasikan dari perspektif kualitas (Lijing Wang, 2020) Pengaruh langsung perekonomian dengan menggunakan model mediating effect untuk menganalisis pengaruh dari pembangunan ekonomi. Efek mediasi ini mengacu pada pengaruh tidak langsungnya variabel independen terhadap variabel dependen melalui variabel mediasi yang mempengaruhi (Ting Gan, Wei Liang, Huacho Yang, Xianchun Liao, 2020) 
Efek mediasi terhadap turnover, efek yang tidak langsung dimoderasi dari mindfulness pada suatu hubungan disposisional . Dari prosedur analisis efek mediasi untuk menganalisis kekuatan prediksi variabel independen terhadap variabel dependen. Dimana tingkat kewaspadaan tinggi menyebabkan efek mediasi stres kerja yang lebih tinggi dalam hubungan dan adanya turnover yang menyebabkan niat untuk berpindah. Hasil ini menimbulkan keraguan tentang efek kewaspadaan (Jong-Hyun Lee Jaeeun Lee, 2020)

Peran efek mediasi bertujuan untuk menjelaskan hubungan yang kompleks antara jaringan social dan kinerja perusahaan meliputi kepercayaan, kemampuan menjual, dan kemampuan harga. Dimana kepercayaan sebagai peran penting dalam jaringan social, yang memungkinkan perusahaan untuk mencapai kinerja yang lebih baik lagi (Pratono, 2018) Efek mediasi berpengaruh positif kepada peforma, seperti dapat memperbaiki hubungan antara dukungan rekan kerja terhadap intensi. Peran mediasi pada faktor-faktor penentu kinerja bisnis untuk memperluas faktor yang mempengaruhi kinerja bisnis, yaitu dengan menambah variabel keunggulan bersaing, dan orientasi kewirausahaan. Peran mediasi juga akan memperbaiki kualitas strategi bisnis, dan etika perilaku penjual terhadap kinerja bisnis. 


\section{Bibliography}

Amare Abawa Esubalew, A. R. (2020). he mediating effect of entrepreneurs' competency on therelationship between Bank finance and performance of micro, small,and medium enterprises (MSMEs). European Research on Management and Business Economic, 87-95.

Araral, E. (2020, November). Why do cities adopt smart technologies? Contingency theory and evidence from the United States. Cities.

Christopher Jung, J. N. (2020, June). Cash for contingencies: How the organizational task environmentshapes the cash-performance relationship. Long Range Planning.

Hayam Wahbaa, K. E. (2015, December). The mediating effect of financial performance on the relationship between social responsibility and ownership structure. Future Business Journal, 1(12), 1-12.

Jong-Hyun Lee Jaeeun Lee, K.-S. L. (2020, June). Moderated Mediation Effect of Mindfulness on the Relationship Between Muscular Skeletal Disease, Job Stress, and Turnover Among Korean Firefighters. Safety and Health at Work, 11(2), 222-227.

Lijing Wang, Y. W. (2020). Performance shaping factors dependence assessment through moderating and mediating effect analysis. Reliability Engineering and System Safety.

Mojgan Mollahassani, P. T. (2020). Assessment of transmission outage Contingencies'effects on biddingstrategies of electricity suppliers. Electrical Power and Energy Systems.

Pratono, A. (2016). Strategic orientation and information technological turbulence: contingency perspective in SMEs. Business Process Management Journal, 22 (2).

Pratono, A. (2018). "From social network to firm performance: The mediating effect of trust, selling capability and pricing capability. Management Research Review, 41(6), 680-700.

Ting Gan, Wei Liang, Huacho Yang, Xianchun Liao. (2020, September 1). The effect of Economic Development on haze pollution (PM2.5) based on a spatial perspective: Urbanization as a mediating variable. Journal of Cleaner Production, 266.

Xiao-Yun, X. F. (2020). Does new venture team power hierarchy enhance or impair new venture performance? A contingency perspective . Journal of Business Venturing. 